\title{
A collection of suggested electronic course templates for use in higher education
}

\author{
Jill W. Fresen ${ }^{\mathrm{a} *}$, Robin K. Hill ${ }^{\mathrm{b}}$ and Fawei Geng ${ }^{\mathrm{a}}$ \\ ${ }^{a}$ Academic IT Services, University of Oxford, Oxford, United Kingdom; ${ }^{b}$ Department of \\ Philosophy, University of Wyoming, Laramie, WY, USA
}

(Received 11 June 2013; final version received 23 October 2013)

The collection of electronic course templates suggested in this article results from collaborative investigation between instructional support staff and academic staff users of the virtual learning environment (VLE) at two institutions, one in the United Kingdom and the other in the United States. The particular VLE in use at both institutions was Sakai, although the experience described here can be applied to the design process and workflow using any VLE that allows the selection and some configuration of standard tools.

We applied the lattice model of Hill, Fresen and Geng (2012) to design and build a set of six course site templates, which are used as the basis on which site owners can easily build new sites in the VLE. As the ultimate goal of template provision is to underpin pedagogy, academics are free to use a template or build a site from scratch, based on their own teaching context, and they may adapt any template according to the pedagogical purpose and nature of the course. The underlying assumptions are that academic staff retain full control over the content, tools and permissions in their new site. The templates are not mutually exclusive - that is, aspects from any template may be incorporated, where applicable, into another one.

We conclude that it is helpful for the VLE support team to take the lead in proposing a set of templates according to the predominant teaching and learning models in use at a particular institution, which may contribute to consistency across course sites and ultimately result in an improved student learning experience.

Keywords: virtual learning environment; learning management system; course templates; pedagogical dimensions; course site properties; faculty support

\section{Introduction}

Part of the work of learning technologists ${ }^{1}$ (also called 'instructional designers') is to support academic staff ('lecturers' or 'instructors') in reflecting on their pedagogical practice and to explore how technologies such as virtual learning environments (VLEs) (also called 'learning management systems' or 'course management systems') may contribute to streamlining the teaching function and enriching the student learning experience. The purpose of this article is to present a collection of suggested electronic templates for academic staff to use as a starting point when embarking on developing a course component (also called a 'site' or 'course site') within an institutional VLE. Evaluating the templates in practice, and their potential impact on teaching and learning, is the subject of further research.

*Corresponding author. Email: jill.fresen@it.ox.ac.uk

Research in Learning Technology 2014. C 2014 J.W. Fresen et al. Research in Learning Technology is the journal of the Association for Learning Technology (ALT), a UK-based professional and scholarly society and membership organisation. ALT is registered charity number 1063519 . http://www.alt.ac.uk/. This is an Open Access article distributed under the terms of the Creative Commons CC-BY 4.0 License (http:// creativecommons.org/licenses/by/4.0/), allowing third parties to copy and redistribute the material in any medium or format and to remix, transform, and build upon the material for any purpose, even commercially, provided the original work is properly cited and states its license. 


\section{J.W. Fresen et al.}

This article (Paper II) is the second in a series of three by the same authors. Paper I, 'Derivation of electronic course templates for use in higher education' (Hill, Fresen, $\&$ Geng, 2012), describes the thinking processes and exploratory attempts to analyse and classify dimensions of course sites leading to a conceptualisation of types of templates. The present article presents the distillation of that process in the form of a collection of electronic templates to be used as a practical starting point for academic staff who embark on setting up a course site in an institutional VLE. Paper III will report on findings after implementing the suggested electronic templates and gathering feedback from academic staff and students.

\section{Background}

This discussion assumes that a higher education institution employs an institutionally supported VLE, which may be a commercial one (such as Blackboard or Desire2Learn), or an open source one (such as Sakai or Moodle). The particular platform currently used by the authors is Sakai; its open-source model means that inhouse developers are able to modify and customise the underlying source code. However, this is not a prerequisite for the collection of templates suggested in this article. The suggestions here may be applied in any higher education institution, insofar as its VLE allows prospects for customisation.

We acknowledge that electronic sites for courses which run totally at a distance have special requirements in terms of enhancing socialisation, interaction and communication between lecturers and students, students and students, and students and learning materials (Anderson, 2004). In this article, the focus is less on pure distance courses; our milieu presupposes a blended learning approach with at least some measure of face-to-face contact between lecturers and students, even if this is infrequent or of short duration.

We understand a 'template' to be a framework for, or initial state of, a course site, intended as a partially built online space to enable lecturers or tutors to 'get started' quickly. 'A template is more developed than a blank site available in the VLE, but it awaits the teaching and learning content - the body of knowledge that constitutes the core materials and activities in the course' (Hill et al., 2012, p. 4).

\section{Underlying assumptions}

Our work is based on three important assumptions:

(1) Academic staff who build an electronic course site based on a template retain full control over the content, tools and permissions in their new site (subject to what their default role in the institutional VLE allows) 'The purpose of a course template is to suggest, not to prescribe' (Hill et al., 2012, p. 4).

(2) Templates suggested in a collection such as offered in this paper are not mutually exclusive - that is, the lecturer or instructor will not necessarily want to focus only on assessment tools, or only on collaboration activities. Aspects from any template may be incorporated, where applicable, into another one, according to the pedagogical purpose and nature of the course. 
(3) The support provided to academic staff in the form of templates should include suggestions for accompanying implementation, clear instructions on how to modify the template and links to appropriate help materials.

\section{Literature snapshot}

The research literature in higher education and technology yields many definitions, purposes and types of 'e-learning templates'. The e-Learning Coach (2011, online) provides the following definition: 'eLearning templates refer to a set of standard screens you can create for a course to provide visual and cognitive continuity'. One should not underestimate the importance of taking cognitive continuity and cognitive load into account. As one's senses are bombarded with myriad demands and stimuli in today's technologically driven world, there is a risk of cognitive 'switch off', if not cognitive 'burnout'. Hence, the goal of designing and producing electronic course templates is to facilitate building electronic course sites by academic staff - quickly and easily, as well as to make the student learning experience more structured and consistent (see Paper III - forthcoming).

Paper I in this series (Hill et al., 2012) investigated 'how to find, describe and categorise course design dimensions that will inform our construction of electronic course templates, embracing the widest variety of notions that are expressed informally by instructors' (p. 5). We proposed a lattice model (Figure 1 in this paper), interweaving Pedagogical Dimensions (Logistical, Practice, Purpose and Participation) with Course Site Properties (User Roles, User Experience, Functionality and Tools, Initial Content and Technical System Settings). We provided two example templates 'Cornerstones' and 'Web 2.0' which reflect respectively 'a strong need for a simple

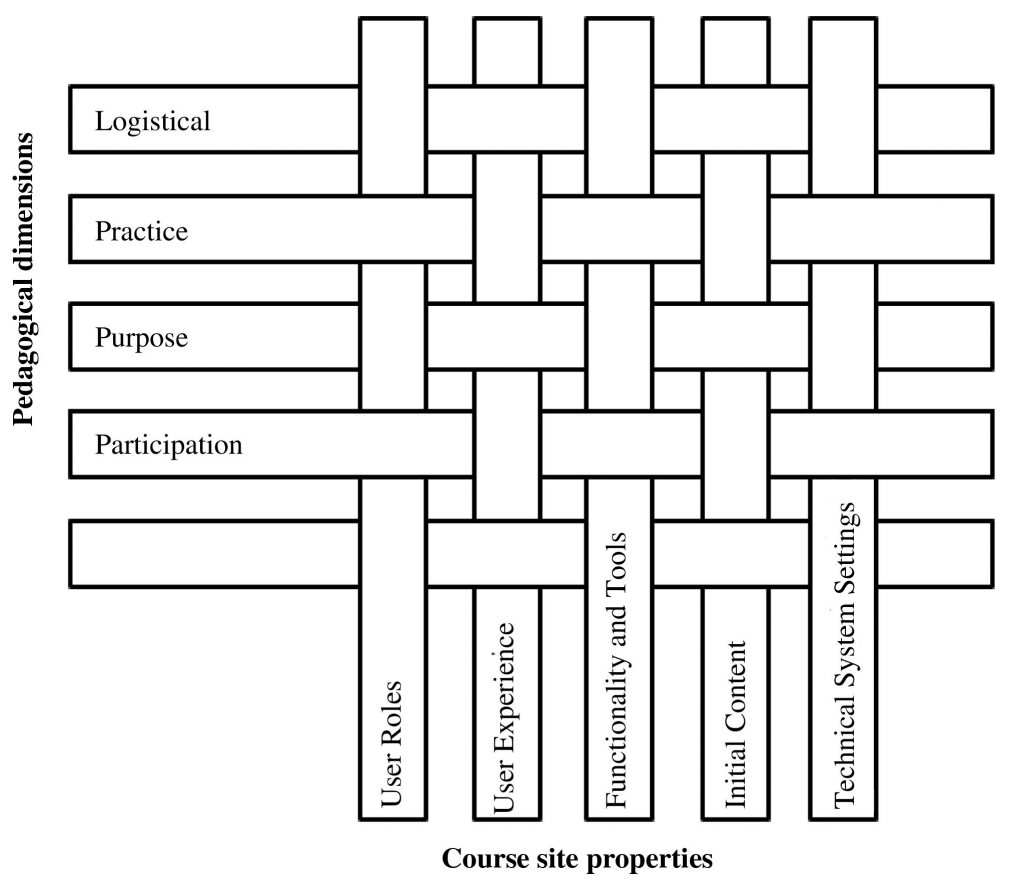

Figure 1. Lattice model for course templates (Source: Hill, Fresen, and Geng, 2012). 


\section{J.W. Fresen et al.}

course template for distribution of materials, teacher-to-student ... and a course template for those instructors who want to foster collaborative student work online, for sharing and assessment' (p. 14).

The Joint Information Systems Committee (JISC) in the United Kingdom found that 'Practitioners teach and learners learn in a context of increasing choice. Effective practice in a digital age includes selecting the most appropriate tools for the purpose' (JISC, 2009, p. 51). Interestingly, for various (certainly understandable) reasons, the uptake amongst academic staff of electronic tools and technologies to support teaching and learning tends to remain low (Fresen, 2011). Certainly, whatever support mechanisms (such as templates) an instructional technology team might consider developing, such tools need to offer clear savings in terms of time, energy and frustration. Woodward (2010) describes the dual demands for an electronic template: 'academic staff should retain flexibility and choice in how they present the detail of their content, and the template should facilitate the work of building a module and not restrict it' (p. 1).

Jara and Mohamad (2007) make the same point in their project which undertook the design of pedagogical templates for e-learning: 'The goal of this set of templates is to help academic staff who are starting to use learning technologies in their teaching and learning, by providing a structured and simplified overview of possible options. The aim is to facilitate the journey into using technology in teaching and learning, rather than prescribing it or defining its limits' (p. 2). Both studies just mentioned (Jara and Mohamed, 2007; Woodward, 2010) report on the development of templates to address specific needs and current practice at their respective institutions. This paper is a similar 'second step' for the current authors - to design, develop and support specific templates, together with guidelines for their use within our particular VLEs.

Jara and Mohamad (2007) distilled two models from the literature as 'offering potentially useful categorisations for our purposes' (p. 4):

(1) Mason's three models (1998, cited by Jara and Mohamad, 2007):

- Content + support model: traditional distance learning courses to which online support has been added;

- Wrap-around model: learning materials prepared specifically for the course, and wrapped around existing materials;

- Integrated model: a course that is purely online and dependent on the creation of a learning community.

(2) Quinsee's three stars incremental model (2004, cited by Jara and Mohamad, 2007):

- One star: Foundation - Basic common model, in which every course has a web presence and module information;

- Two star: Integration - Intermediate content + communication model, which builds on the basic module by embedding e-learning more deeply in the course design;

- Three star: Innovation - Advanced and integrated model, in which all interaction can be undertaken online.

These two models, and indeed Jara and Mohamad's (2007) resulting set of seven templates, focus on the degree of face-to-face and online learning components in a course - in other words the position of a course along the blended learning 
continuum. This is certainly one aspect of course design; our collection aims to embrace broader aspects according to the lattice model (Hill et al., 2012).

\section{The lattice model of course dimensions and site properties}

The lattice model (Figure 1) illustrates the organic interplay between pedagogical dimensions and course site properties proposed by Hill et al. (2012).

Although the lattice model may suggest that pedagogical dimensions are given, and course site properties are the results of the design exercise, the actual state of affairs is that any cell may lead to any other, or may leave all paths open. Two examples are provided below to illustrate possible points of intersection. In what follows, the dimensions and properties are indicated in bold (row and column elements in Figure 1), and factors that they contain are indicated in italics. For details of the purpose of the lattice model, the pedagogical dimensions, course site properties and the factors they contain, see Hill et al. (2012).

Example 1: One of the factors in the Practice dimension is Course activity type. An activity such as a field trip may combine with the Logistical dimension Size of Student Enrolment to determine a reasonable size of groups, not only for the field trip but also for online collaboration before and after the trip. The User Experience Documentation factor should make available in advance, the procedures and expectations for the excursion. The activity may require a User Role such as 'teaching assistant' for group leaders to post group findings after the trip. It is far from necessary, however, that such a User Role should be included; the posting of group findings may be managed by some other role or associated permissions. Thus, the lattice model illustrates not decisions to be taken but aspects for consideration and how they may affect one another.

Example 2: The Logistical dimension Academic Group, if the group emphasises experimentation (for example, a science department), might intersect the Initial Content property with the provision of a lab manual, which might then determine that the Participation dimension Extent of Web Work is appropriately 'web-enhanced' rather than any of the other values for that factor. What other course site properties should be considered? Perhaps other properties might be considered, such as a discussion and assessment addressing lab safety, or perhaps none, if those matters are handled elsewhere.

In short, the lattice model is descriptive rather than prescriptive; a heuristic rather than an algorithm. The model, with its enumeration of factors, provides ideas that may or may not apply to any given teaching project. To claim otherwise would be to subvert the creativity and agility required for good teaching. Concrete suggestions, such as those presented in a template, however, can provoke substantial thought about pedagogy; that is the reason for developing templates in the first place.

\section{Collection of electronic templates}

This section offers a collection of six templates for course sites in a VLE, in a blended learning situation. The set does not attempt to cover the full range of possibilities, or to include all factors that may have an influence on a particular course site. It simply reflects one possible distillation that is intended to be practical, easy to understand and useful to academic staff before, or even without, support from learning technologists. 


\section{$J . W$. Fresen et al.}

The hope at the beginning of the project was to discover some sort of visual mechanism (a continuum, a stepladder, a grid?) to represent the collection of templates. However, we came to the realisation that it does not make sense to structure the collection in terms of a progression or hierarchy of any sort, since we seek to avoid implying that 'more' e-learning implies better, more highly rated or more innovative learning. Thus, the collection is presented simply as a 'group' of templates (see Figure 2). Note that in Figure 2, the 'Content' template replaces the 'Cornerstones', and the 'Web 2.0' remains the same as the example provided in Paper I (Hill et al., 2012).

Some of the templates conceptualised here are customised for a traditional, face-to-face, research-intensive university based on the British (Oxbridge) tutorial model. In such a university, students are free to select which lectures they wish to attend to support their learning pathway, and undergraduate students participate in small group tutorials under the guidance of an expert tutor; hence, the inclusion of a 'Lecture series' template and a 'Tutorials' template. In a traditional, primarily face-to-face, research university based on the American model, with discussion or recitation components to classes, these two templates might be combined into what might be called 'Enrichment' (offering supporting learning materials, over and above the basic 'Content' provision of organisational information).

We do not favour the more complex templates, sophisticated and feature-rich as they may be, over the simpler ones but rather encourage the selection of a template at the level appropriate to the pedagogical plan. Academic staff should view their course site setup and maintenance process as a balance between their need to make use of supporting technology and the amount of their time and effort that they can afford to commit to using the technology effectively.

\section{Template building process}

The template building process was the result of a combination of the theoretical analysis undertaken in Paper 1, the practical experience of the authors and the particular institutional context. We met as a small team of learning technologists to agree on the wording for the purpose of each template, appropriate tools to incorporate and how to surface existing help resources to provide just-in-time support.

We started by using the conceptual basis and the two examples that emerged from our earlier work (Hill et al., 2012). We trimmed down the lattice model (see Figure 1), incorporating an eclectic mix of its dimensions (shown in bold in the following text),

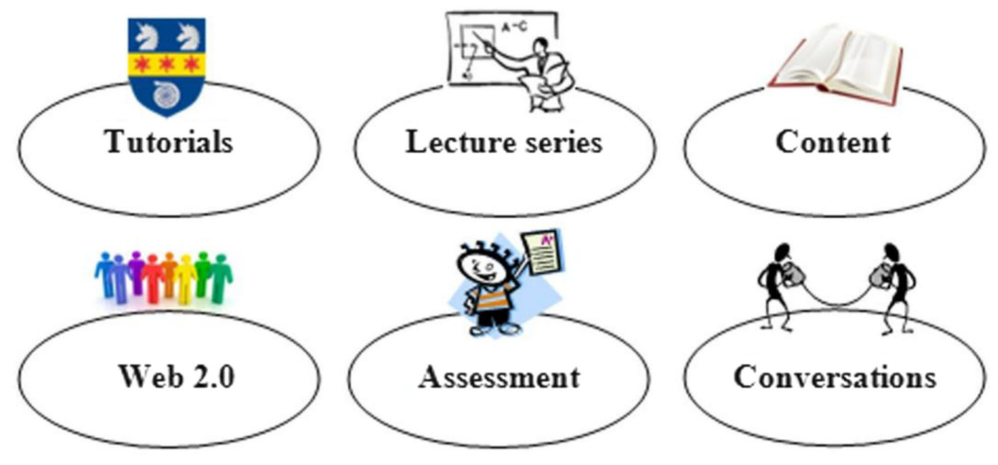

Figure 2. Collection of six suggested course site templates. 
and leaving academic staff the freedom to make their own adjustments, particularly with regard to the Pedagogical Dimensions. Being a team of learning technologists supporting the use of the institutional VLE, we focused more intensively on Course Site Properties. As we explained in the earlier work, we refined our original intention to derive a mapping from Pedagogical Dimensions to Course Site Properties into a more flexible interpretation of teaching needs.

User Roles are the pre-defined, standard roles within our VLE, with their associated default permissions. The User Experience property was translated into detailed help and support for site owners regarding the user interface ('Instructions on how to build this site'), together with reasons for incorporating certain features or tools, suggestions and links to help guides and tutorials. This property also reflects the recommended Guidance afforded to instructors (Hill et al., 2012). Figure 3 shows the detailed instructions and Figure 4 shows the links to further help and guidance for one of the templates - the 'Tutorials' template.

In terms of Functionality and tools, we agreed on a basic tool set for each template, which we 'seeded' with Initial content. For example, in the 'Lecture series' template, we included the Forums (Discussions) tool in order to facilitate on-going discussions before and after lecture sessions, and we created a basic structure of forums and topics to guide the site owner. We included an RSS News tool, pointing to a feed that can easily be modified by the site owner in terms of relevance to their particular subject discipline.

No special Technical settings were implemented, beyond the customisations and extra features already incorporated in the open-source VLE currently in use. We set up specific folders in the file storage area, depending on the purpose of the template, for example, a set of folders for an 8-week 'Lecture series': Week 1, Week $2, \ldots$ Week 8 . Other examples of translating pedagogical concepts into technical settings are incorporating group-aware tools (such as Discussion Forums and other communication tools) in templates designed to foster collaborative learning,

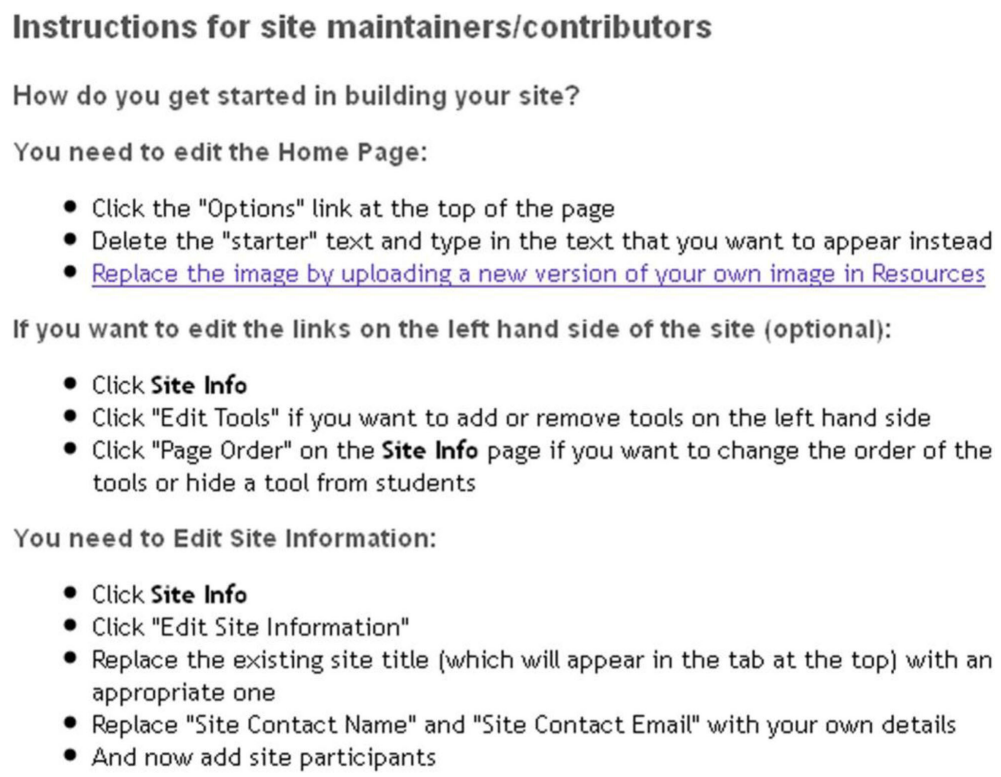

Figure 3. Instructions to site owners ('Tutorials' template). 
J.W. Fresen et al.

Brief guides for tools used in this template:

- 스 Home Page

- 2tudent Resources

- 2Websites

- 4 粮

- 4 Announcements

- Assignments

- Sign-up

- Resources

- $\underline{\text { Site Info }}$

- (1) Site Stats

- (9) Help

Other tools suggested for a tutorial site:

- Forums: set up various discussion topics for your tutees to carry on discussions outside of face-to-face tutorials

- $\checkmark$ Email Archive: set up a mailing list for site-wide communication

- Email Sender: send emails to individuals or sub-groups of tutees in this site

Further help and support

The WebLearn Guidance site provides additional resources, help and guidance.

Figure 4. Links to further help and guidance ('Tutorials' template).

and a tool such as 'Sign up' to enable students to sign up for tutorial sessions in the 'Tutorials' template.

\section{Recommended components}

It became apparent that certain components are recommended in all course sites, regardless of their purpose, such as lecturer contact details, and a files and folders area to host and share resources. The list of recommended components (or 'minimum requirements') will depend on the particular institution and VLE in use - this is the list used at the British institution in this study:

\section{Basic features}

These features usually appear on the Home Page:

- Site (course) title

- Sub-title or welcome by-line

- Department or college logo/photo of lecturer/tutor or suitable theme photo

- Welcome message

- Lecturer/tutor contact information: email, work phone, office location, office hours, link to departmental or personal web page

- About the site:

- purpose of the site

- main components of the site and how to access them

- expected participation levels (lecturer and students)

Course materials and delivery

A typical course site will contain a selection of course materials to support students outside the face-to-face environment: 
- Prerequisites, for example, reading list, course outline, learning outcomes (syllabus)

- Criteria for course materials:

- All material and links are up to date

- Students can see/view the content without requiring special applications which are not commonly available

- Third-party copyright material in the site is clearly acknowledged, indicating that permission for its use has been granted

- Assessment (formative and summative) plan

- Student feedback opportunities or tools

\section{Recommended tools}

Some of the tools mentioned may be particular to the Sakai VLE. Other VLEs will almost certainly contain similar tools, possibly with different names.

- Home Page - for 'basic features' listed above

- Resources - folders and files area for hosting content, student resources, and so on

- Search - for searching content in the site, including inside files stored in Resources

- Site Stats - for collecting and showing site statistics by user, event or resource

\section{Optional tools}

Depending on the purpose of the site, we selected from the following categories of standard tools:

- Organisational tools

Schedule, Signup tool, Syllabus, Surveys, and so on

- Content provision tools

Reading lists, Podcasts, News feeds, Web links, Wiki, and so on

- Communication tools

Announcements, Email Archive, Mail Sender, Chat, Forums (discussions), and so on

- Assessment tools

Quizzes, Assignments, Graded discussions, Polls, and so on

Although the list of recommended common components may seem long enough to stifle variance, they offer a basic teaching delivery platform that can be arranged and augmented according to the purpose of each template. The six templates are itemised in Tables 1, 2 and 3, showing the purpose, description, pedagogical approach, functionality and tools, initial content, user expectations and user roles in each case.

As we concluded in Paper I (Hill et al., 2012), the tool set alone is neither necessary nor sufficient to define a pedagogically worthwhile template. We intend that the various tools be pressed into service in the way appropriate to the 
Table 1. 'Tutorials' and 'Lecture series' templates.

\begin{tabular}{|c|c|c|}
\hline Template name: & 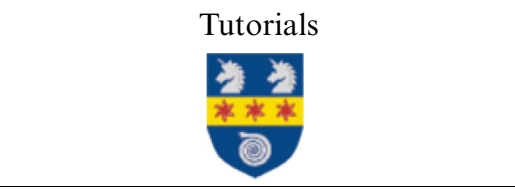 & Lecture series \\
\hline Purpose & $\begin{array}{l}\text { To facilitate small group tutorial } \\
\text { work and submission of weekly } \\
\text { essays (written tasks) }\end{array}$ & $\begin{array}{l}\text { To provide supporting material for } \\
\text { a series of lectures, such as lecture } \\
\text { notes, reading lists, and extra } \\
\text { enrichment materials }\end{array}$ \\
\hline Description & $\begin{array}{l}\text { An area for a tutor to communicate } \\
\text { with his or her tutees, either all } \\
\text { together, or within small subgroups } \\
\text { to enable group work, preparation } \\
\text { before face-to-face tutorials and } \\
\text { submission of tasks for assessment }\end{array}$ & $\begin{array}{l}\text { An online course component to host } \\
\text { course notes, written, audio, and } \\
\text { visual material, and links to } \\
\text { interesting websites that expand } \\
\text { upon the content of the course }\end{array}$ \\
\hline $\begin{array}{l}\text { Pedagogical } \\
\text { approach/tips }\end{array}$ & $\begin{array}{l}\text { Delivery of essay instructions, model } \\
\text { answers; online submission of essays } \\
\text { (assignments); group-wide email list; } \\
\text { signing up for tutorial sessions; peer } \\
\text { evaluation of essays }\end{array}$ & $\begin{array}{l}\text { Use authoritative external websites } \\
\text { and provide annotations. Limit the } \\
\text { size of media and image files. Ask } \\
\text { students for suggestions and } \\
\text { contributions of resources. Work } \\
\text { online resources into classroom } \\
\text { discussion, as you would do with } \\
\text { other supplementary learning } \\
\text { materials. }\end{array}$ \\
\hline $\begin{array}{l}\text { Functionality } \\
\text { and tools }\end{array}$ & $\begin{array}{l}\text { Home Page, Resources, Email } \\
\text { (site-wide), Mail Sender (group } \\
\text { specific), Signup tool, Schedule, } \\
\text { Assignments, Reading Lists }\end{array}$ & $\begin{array}{l}\text { Home Page, Resources, Reading } \\
\text { Lists, Web links, Podcasts, News }\end{array}$ \\
\hline Initial content & $\begin{array}{l}\text { Basic features, plus: } \\
\text { Instructions for tasks, model } \\
\text { answers (where appropriate); } \\
\text { Links to departmental website, } \\
\text { past exam papers, professional or } \\
\text { subject-specific websites }\end{array}$ & $\begin{array}{l}\text { Basic features, plus: } \\
\text { Lecture lists, dates, times and venues; } \\
\text { syllabus (course outline), reading } \\
\text { lists }\end{array}$ \\
\hline $\begin{array}{l}\text { User } \\
\text { expectations }\end{array}$ & $\begin{array}{l}\text { Regular activity required, including } \\
\text { pre-reading before tutorials, online } \\
\text { submission of tasks }\end{array}$ & $\begin{array}{l}\text { Use the site as a collection of lecture } \\
\text { resources. No interaction or activity } \\
\text { is expected from students, besides } \\
\text { exploring the rich content provided. }\end{array}$ \\
\hline User roles & $\begin{array}{l}\text { Add tutees to the course site } \\
\text { Default permissions for all tools }\end{array}$ & $\begin{array}{l}\text { Site can be open to all staff and } \\
\text { students of the institution } \\
\text { Grant students permission to upload } \\
\text { materials }\end{array}$ \\
\hline
\end{tabular}

template's learning goals. For example, each of the last four templates includes a Wiki tool - in 'Content', to build a Glossary (perhaps with student references and input); in 'Assessment', to clarify exam question raised by students; in 'Web 2.0', for discussion among students and external guests or experts; in 'Conversations', to encourage student questions on all activities. The Assignments tool would collect preliminary work and provide formative feedback in the 'Tutorials' template, and the same tool could be used for graded work in the 'Assessment' template. 
Table 2. 'Content' and 'Assessment' templates.

\begin{tabular}{|c|c|c|}
\hline Template name & Content & Assessment \\
\hline Purpose & $\begin{array}{l}\text { To give students permanent access to } \\
\text { the syllabus, lecture notes and } \\
\text { organisational information }\end{array}$ & $\begin{array}{l}\text { To enable more consistent and } \\
\text { rigorous assessment of student } \\
\text { learning }\end{array}$ \\
\hline Description & $\begin{array}{l}\text { A repository of organisational } \\
\text { documents and learning materials; } \\
\text { you can set up these materials well in } \\
\text { advance, and open them at the start } \\
\text { of the term, according to a } \\
\text { predetermined schedule, or manually, } \\
\text { as necessary }\end{array}$ & $\begin{array}{l}\text { A collection of tools to support } \\
\text { assessment and feedback on student } \\
\text { learning in an on-going way, } \\
\text { including self and peer assessment }\end{array}$ \\
\hline $\begin{array}{l}\text { Pedagogical } \\
\text { approach/tips }\end{array}$ & $\begin{array}{l}\text { Instructor }{ }^{2} \text {-to-student, or } \\
\text { administrator-to-student; delivery of } \\
\text { lecture notes, reading lists and } \\
\text { administrative information }\end{array}$ & $\begin{array}{l}\text { Online tests or quizzes are best used } \\
\text { for formative self-assessment. Make } \\
\text { use of the feedback options to } \\
\text { explain common misconceptions } \\
\text { and to redirect study. Peer review } \\
\text { can be enabled using the Discussions } \\
\text { tool with student attachments. The } \\
\text { Drop Box can be used to share } \\
\text { private task documents between } \\
\text { instructor and student, not } \\
\text { necessarily for grading }\end{array}$ \\
\hline $\begin{array}{l}\text { Functionality } \\
\text { and tools }\end{array}$ & $\begin{array}{l}\text { Home Page, Resources (files and } \\
\text { folders), Syllabus, Glossary (can be in } \\
\text { Wiki tool), Announcements, Reading } \\
\text { Lists }\end{array}$ & $\begin{array}{l}\text { Home Page, Schedule, Quizzes, } \\
\text { Assignments, graded Discussion } \\
\text { forums, Polls, Drop Box, Wiki }\end{array}$ \\
\hline Initial content & $\begin{array}{l}\text { Basic features, plus: } \\
\text { Course handbook/outline/syllabus, } \\
\text { departmental timetable }\end{array}$ & $\begin{array}{l}\text { Basic features, plus: } \\
\text { Instructions for the assignments, } \\
\text { seeded discussion topics, initial Wiki } \\
\text { pages }\end{array}$ \\
\hline $\begin{array}{l}\text { User } \\
\text { expectations }\end{array}$ & $\begin{array}{l}\text { Use the site as a collection of } \\
\text { information and other resources; no } \\
\text { activity expected or required }\end{array}$ & $\begin{array}{l}\text { Completion of assessment tasks } \\
\text { before due date; participation in } \\
\text { group activities, if provided; } \\
\text { synthesis of model answers, } \\
\text { if supplied }\end{array}$ \\
\hline User roles & $\begin{array}{l}\text { Site can be open to all students } \\
\text { in the department or cohort } \\
\text { (e.g. undergraduates) } \\
\text { Default permissions for all tools }\end{array}$ & $\begin{array}{l}\text { Site is restricted to site participants } \\
\text { (enrolled students) who are added to } \\
\text { the course site } \\
\text { Default permissions for all tools }\end{array}$ \\
\hline
\end{tabular}

\section{Technical process and difficulties encountered}

Usually an instructor building a site in the Sakai VLE would be a site member with the required 'maintain' (design and build) permission. However, since the templates were to be the basis for creating new sites, we clearly could not be site members in the templates - status which would be perpetuated for all new sites. At the British university, we therefore used our 'admin' login accounts to enable us to build the templates without actually being site members. (The American university awaits a 
Table 3. 'Web 2.0' and 'Conversations' templates.

\begin{tabular}{|c|c|c|}
\hline Template name & 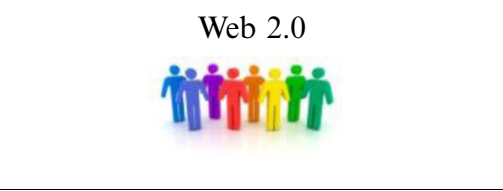 & Conversations \\
\hline Purpose & $\begin{array}{l}\text { To increase participation and } \\
\text { interaction, and foster more } \\
\text { collaboration, in and out of the } \\
\text { classroom }\end{array}$ & $\begin{array}{l}\text { To encourage on-going, preserved } \\
\text { communication between you and your } \\
\text { students, in and out of the classroom }\end{array}$ \\
\hline Description & $\begin{array}{l}\text { The site includes collaborative tools } \\
\text { for students, and you, to share } \\
\text { reflections on particular topics and } \\
\text { to contribute to building the course }\end{array}$ & $\begin{array}{l}\text { The site focuses on the use of the } \\
\text { array of communication tools } \\
\text { available, to replace messages on a } \\
\text { notice board or repetition of } \\
\text { questions and answers between } \\
\text { individuals }\end{array}$ \\
\hline $\begin{array}{l}\text { Pedagogical } \\
\text { approach/tips }\end{array}$ & $\begin{array}{l}\text { Collaboration, student-to- } \\
\text { instructor and student-to-student; } \\
\text { social interaction amongst students; } \\
\text { group project work }\end{array}$ & $\begin{array}{l}\text { Communication: student-to- } \\
\text { instructor and student-to-student; } \\
\text { social interaction amongst students. } \\
\text { Plan the administrative message } \\
\text { vehicle (site-wide email or course } \\
\text { announcements?) and deliver } \\
\text { consistently. Understand the intention } \\
\text { and workflow of each communication } \\
\text { tool, and explain their roles to your } \\
\text { students in simple terms. Use the } \\
\text { synchronous Chat tool for last minute } \\
\text { online interchanges as exams } \\
\text { approach }\end{array}$ \\
\hline $\begin{array}{l}\text { Functionality } \\
\text { and tools }\end{array}$ & $\begin{array}{l}\text { Home Page, Resources, Discussion } \\
\text { forums, Wiki, Chat, Email - all } \\
\text { group sensitive where the tool } \\
\text { allows }\end{array}$ & $\begin{array}{l}\text { Home Page, Resources, } \\
\text { Announcements, Email, Discussion } \\
\text { forums, Wiki, Chat }\end{array}$ \\
\hline Initial content & $\begin{array}{l}\text { Basic features, plus: } \\
\text { Seeded discussion topics; initial } \\
\text { Wiki pages }\end{array}$ & $\begin{array}{l}\text { Basic features, plus: } \\
\text { Seeded discussion topics; initial Wiki } \\
\text { pages }\end{array}$ \\
\hline $\begin{array}{l}\text { User } \\
\text { expectations }\end{array}$ & $\begin{array}{l}\text { Regular activity required to build } \\
\text { an online community }\end{array}$ & $\begin{array}{l}\text { Regular activity required to keep in } \\
\text { touch with fellow students and share } \\
\text { ideas about the subject, questions and } \\
\text { answers; instructor should clarify } \\
\text { their expected level and frequency of } \\
\text { participation }\end{array}$ \\
\hline User roles & $\begin{array}{l}\text { Add enrolled students to the course } \\
\text { site; allow for temporary external } \\
\text { visitors or guests } \\
\text { Allocate 'create' permissions for } \\
\text { relevant tools where not already the } \\
\text { default }\end{array}$ & $\begin{array}{l}\text { Site is restricted to site participants } \\
\text { (enrolled students) who are added to } \\
\text { the course site } \\
\text { Grant students permission to upload } \\
\text { and share files }\end{array}$ \\
\hline
\end{tabular}

new VLE that will afford similar opportunities for the presentation of templates to instructors, and implementation by learning technologists.)

At the British institution, day-to-day management and use of the VLE service is devolved to departments and schools. Staff members can create their own sites, if they have the required permissions to do so from their local VLE coordinator. 
We thus built the choice of a template into the site creation process (see Figure 5). We purposefully made the default option 'create from template', requiring the site owner to select a template from among the choices offered. This helps to promote awareness and use of the templates and thus enhance consistency across all new sites created.

We experienced some technical issues in creating a new site based on a template, for example, some features did not copy over correctly to the newly created site (such as the URL for the site logo), and some tool default states had to be modified to be more general (such as setting the Site Stats tool to record activity across all tools, in case the instructor adds other tools later).

Fortunately, the implementation of the templates is an on-going exercise in continuous improvement, without any completion deadline; the technical issues were easily overcome and ultimately contributed to the robustness of the templates.

\section{Evaluating the templates}

Pedagogical proposals such as these templates, concrete or flexible, are difficult to evaluate in higher education, where ideas undergo constant refinement, and measurement defies quantification. The very goal, to guide rather than force the instructor, exposes the difficulties of measuring success or failure of such educational constructs. Is a template successful if it suggests teaching methods to faculty that provides good teaching outcomes (measured in some way), even if the templates themselves have little to do with it? Is a template successful even if it is edited so thoroughly that it bears no relation to the original? Are a set of templates successful even if they are not, in an instructor's final plan, used at all? Here, a broad definition of success that embraces all of these situations is warranted, to be explored in subsequent

\section{New Site}

Site Type
Choose the type of site you want to create. Only instructors can create official course websites
Instructors and students can create project websites. NOTE: Students, if you do not see a tab
for your course, contact your instructor for information about when your official course website
will be available.
You can create a new site in one of two ways. A. Build-Your-Own site (for experienced users)
lets you choose individual site tools and functions. A. Template-based site (recommended for
new users) comes pre-loaded with essential tools and functions. Please note, you can add or
remove tools from either type of site, once created.
Build your own site
Create site from template
"-- select template --
$\begin{aligned} & \text {-- select template -- } \\ & \text { project - Template for content } \\ & \text { project - Template for tutors } \\ & \text { project - Template for assessment } \\ & \text { proiect - Template for lecturers }\end{aligned}$

Figure 5. New site creation process, with the default being to create it from a template. 


\section{Template sites}

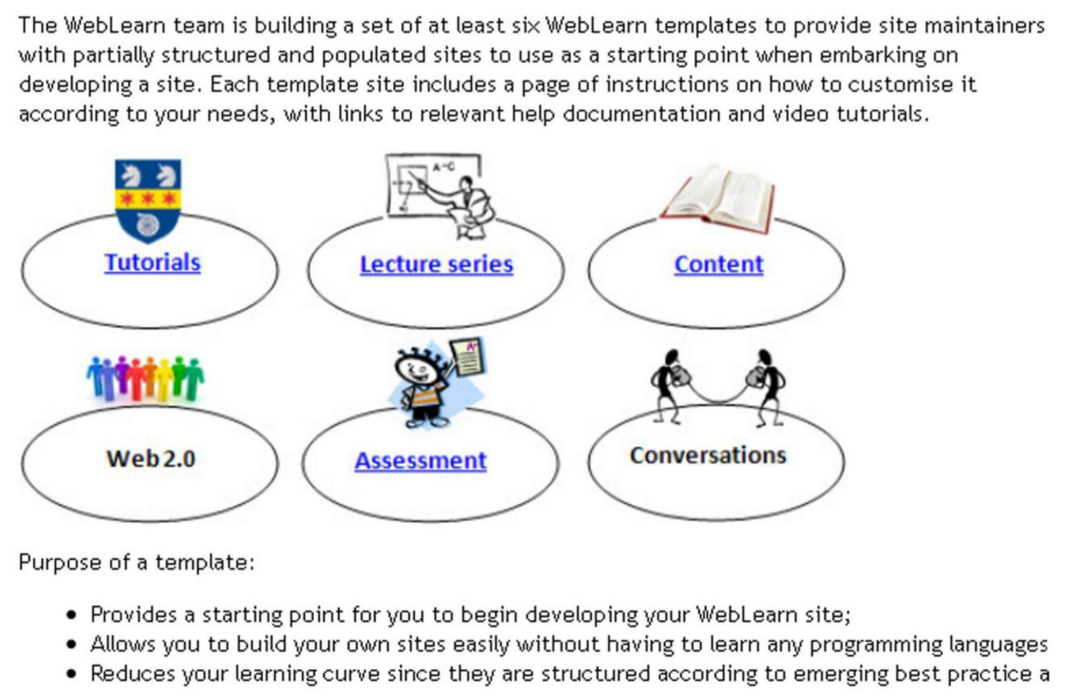

Figure 6. Clickable read-only examples of the templates available for perusal.

research. Such reflection will inform the research questions to guide the design of the evaluation exercise being planned for the third paper in this series.

\section{Making the templates available and promoting their use}

After building the templates in the VLE, we realised that we also needed 'example' versions of the templates for prospective academic staff users to peruse - 'read-only' versions. We thus duplicated each template and made the read-only versions available on the help and support site (See Figure 6):

The sample templates are publicly available. The web page displayed in Figure 6 can be accessed from https://weblearn.ox.ac.uk/info - select 'Template sites' in the 'Showcase' box.

The templates were promoted via the VLE user group, departmental newsletters, mailing lists, blog posts (Geng and Marshall, 2012; Highton, 2013) and various other institutional marketing mechanisms. Face-to-face training sessions now incorporate a demonstration of how to create a new site based on a template. Anecdotal evidence suggests that responses from academic staff are positive; they have expressed appreciation of the fact that they do not have to start from a blank site, and that they can get their site 'up and running' in a short space of time. Students anticipate that further use of the site templates will promote a more structured learning experience from their point of view (see Paper III, forthcoming).

\section{Conclusions}

This article describes the practical experience of applying the lattice model for course site templates (Hill et al., 2012). In particular, it illustrates that many interlocking parameters must be taken into account when designing and building course site 
templates for use by academic staff members. The focus of the suggested templates ranges from the efficient distribution of materials, to collaborative learning, to assessment, thus satisfying a variety of pedagogical approaches that have been shown to work well in the field of technology-enhanced learning (Weller, 2002). The standard tools in a VLE are interpreted as aids to a range of teaching activities, under the pedagogical guidance afforded by the template.

In summary, the method of experience and expedience may be best in structuring and producing a set of course site templates. This paper's contribution is the set of six comprehensive templates designed for different pedagogical scenarios. The templates were developed using an exploratory method, with the lattice model serving as inspiration and interpretation of the factors of a course site. Although it is helpful for the VLE support team to take the lead in proposing a set of templates according to the predominant teaching and learning models in use, the best course templates may emerge from observation and codification of the patterns of use of the VLE in a particular higher education institution.

\section{Notes}

1. This article employs UK terminology; where necessary, equivalent US terms are provided on the first mention.

2. The term 'instructor' is used to refer to either a lecturer or tutor who is facilitating the learning experience.

\section{References}

Anderson, T. (2004) 'Toward a theory of online learning', in Theory and Practice of Online Learning, ed T. Anderson. Athabasca University, Athabasca, [online] Available at: http:// cde.athabascau.ca/online_book/ch2.html

Fresen, J. W. (2011) 'Factors influencing lecturer uptake of e-learning', in Special Edition on LAMS and Learning Design, eds J. Dalziel, C. Alexander, J. Krajka \& R. Kiely, Teaching English with Technology, vol. 11, no. 1, pp. 81-97, [online] Available at: http://www. tewtjournal.org/VOL\%2011/ISSUE\%201/volume_11_issue_01-08_article_06.pdf

Geng, F. \& Marshall, A. (2012) 'Using templates to create new sites', Blog post, [online] Available at: http://blogs.oucs.ox.ac.uk/adamweblearn/2012/06/using-templates-to-createnew-sites/

Highton, M. (2013) 'Chicken and egg', Blog post, [online] Available at: http://blogs.oucs.ox.ac. $\mathrm{uk} / \mathrm{melissa} / 2013 / 04 / 01 /$ chicken-and-egg/

Hill, R. K., Fresen, J. W. \& Geng, F. (2012) 'Derivation of electronic course templates for use in higher education', Research in Learning Technology, vol. 20, [online] Available at: http:// dx.doi.org/10.3402/rlt.v20i0.18665

Jara, M. \& Mohamad, F. (2007) Pedagogical Templates for e-Learning. Occasional Papers in Work-based Learning 2. University of London, Institute of Education, WLE Centre, London.

JISC. (2009) 'Effective practice in a digital age', [online] Available at: http://www.jisc.ac.uk/ media/documents/publications/effectivepracticedigitalage.pdf

The e-Learning Coach. (2011) 'eLearning templates', [online] Available at: http://theelearning coach.com/media/graphics/elearning-templates

Weller, M. (2002) Delivering Learning on the Net, Kogan Page, London.

Woodward, S. (2010) The University of Glamorgan Blackboard Template Project: Balancing Consistency with Flexibility, Case study for EvidenceNet, The Higher Education Academy, York, UK, [online] Available at: http://www.heacademy.ac.uk/assets/EvidenceNet/Case_ studies/woodward.pdf 